\title{
Indomethacin Serves as a Potential Inhibitor of Protein Phosphatases
}

\author{
Takeshi Kanno ${ }^{\mathrm{a}}$ Ayako Tsuchiya ${ }^{\mathrm{a}}$ Tadashi Shimizu $^{\mathrm{b}}$ Akito Tanaka ${ }^{\mathrm{b}}$ Tomoyuki \\ Nishizakia,b \\ aDivision of Bioinformation, Department of Physiology, Hyogo College of Medicine, 1-1 Mukogawa- \\ cho, Nishinomiya; 'baboratory of Chemical Biology, Advanced Medicinal Research Center, Hyogo \\ University of Health Sciences, 1-3-6 Minatojima, Chuo-ku, Kobe
}

\section{Key Words}

Indomethacin $•$ Protein phosphatase $1 \cdot$ Protein phosphatase $2 \mathrm{~A} \cdot$ Protein tyrosine phosphatase $1 \mathrm{~B} \cdot \mathrm{Ca}^{2+} /$ calmodulin-dependent protein kinase II

\begin{abstract}
Background/Aims: We have shown that indomethacin has the potential to activate $\mathrm{Ca}^{2+} /$ calmodulin-dependent protein kinase II (CaMKII), regardless of cyclooxygenase (COX) inhibition. To understand the underlying mechanism, the present study investigated the effect of indomethacin on protein phosphatases such as protein phosphatase 1 (PP1), protein phosphatase 2A (PP2A), and protein tyrosine phosphatase 1B (PTP1B). Methods: Activity of CaMKII was assayed in cultured rat hippocampal neurons and under the cell-free conditions. Activities of protein phosphatases were monitored under the cell-free conditions. Indomethacin binding assay was carried out using a fluorescein-conjugated indomethacin. Results: Indomethacin enhanced CaMKII activity in cultured rat hippocampal neurons, that is abolished the CaMKII inhibitor KN-93. In the cell-free assay, no CaMKII activation was obtained with indomethacin, but indomethacin otherwise inhibited PP1 in a concentration (10 $\mu \mathrm{M}-1 \mathrm{mM}$ )-dependent manner, the maximum reaching $70 \%$ of basal levels. This indicates that indomethacin indirectly activates CaMKII due to PP1 inhibition. Likewise, indomethacin still inhibited PP2A and PTP1B in a concentration (10 $\mu \mathrm{M}-1 \mathrm{mM})$-dependent manner, reaching 80 and $10 \%$ of basal levels at $1 \mathrm{mM}$, respectively. In the indomethacin binding assay, indomethacin bound to all the investigated protein phosphatases. Conclusion: The results of the present study indicate that indomethacin inhibits PP1, PP2A, and PTP1B, possibly through its direct binding and that the inhibitory effect of indomethacin on PP1 could cause indirect CaMKII activation. This may represent the novel indomethacin action.
\end{abstract}




\section{Introduction}

Indomethacin is an inhibitor of COX-1 and -2 , that inhibits prostaglandin synthesis from arachidonic acid, and widely used to reduce fever and pain. [1-4]. In our earlier study, indomethacin ameliorated scopolamine-induced spatial learning and memory impairment for rats or age-related spatial learning and memory deterioration for senescence-accelerated mouse-prone 8 mice [5]. In addition, indomethacin could still enhance learning and memory potentials for healthy humans and normal rats [5]. In explanation of these actions, indomethacin stimulated presynaptic glutamate release and facilitated hippocampal synaptic transmission in a CaMKII-dependent manner [5]. Indomethacin, alternatively, potentiated $\alpha 7 \mathrm{ACh}$ receptor responses in a protein kinase C (PKC)-dependent manner [6]. Interestingly, indomethacin selectively activated PKC- $\varepsilon$ through its direct binding [7]. Indomethacin, thus, appears to be implicated in the activation of CaMKII or PKC, regardless of COX inhibition.

We have earlier found that the linoleic acid derivative DCP-LA serves as a direct and selective activator of $\mathrm{PKC}-\varepsilon$ and stimulates neurotransmitter release by enhancing presynaptic $\alpha 7$ ACh receptor activities [8, 9]. In addition, DCP-LA stimulates delivery of the AMPA receptor subunits such as GluR1 and GluR2 towards the plasma membrane by activating CaMKII [10]. A striking finding is that DCP-LA did not activate CaMKII under the cell-free conditions but that DCP-LA inhibits PP1, a protein serine/threonine phosphatase [10]. PP1 inactivates CaMKII by dephosphorylating phosphorylated CaMKII, an active form of CaMKII (Fig. 1). DCP-LA, accordingly, indirectly activates CaMKII by inhibiting PP1 to prevent CaMKII dephosphorylation, i.e., CaMKII inactivation. Then, we guessed that indomethacin might exert its actions on CaMKII and PKC by the mechanism sharing with DCP-LA.

The present study was conducted to understand the mechanism underlying indomethacin-induced CaMKII activation. To address this point, we monitored activities of CaMKII and protein phosphatases such as PP1, PP2A, and PTP1B in cultured rat hippocampal neurons and under the cell-free conditions, and carried out indomethacin binding assay using a fluorescein-conjugated indomethacin. We show here that indomethacin inhibits PP1, PP2A, and PTP1B, with the potential varying among protein phosphatases, possibly through its direct binding, and that the PP1 inhibition could be a factor responsible for CaMKII activation.

\section{Materials and Methods}

\section{Animal care}

All procedures have been approved by the Animal Care and Use Committee at Hyogo College of Medicine and were in compliance with the National Institutes of Health Guide for the Care and Use of Laboratory Animals.

\section{Cell culture}

The hippocampus was removed from the embryonic Wistar rat brain (gestational age, 18 days) under ether anesthesia and dissociated with a Pasteur pipette. Then, cells were seeded on poly-D-lysine-coated 96-well plates and grown in Neurobasal (GIBCO, Carlsbad, CA, USA) supplemented with B27 (GIBCO)(50:1), $2.5 \mathrm{mM}$ glutamine, $50 \mu \mathrm{M}$ glutamate, penicillin (final concentration, $100 \mathrm{U} / \mathrm{ml}$ ), and streptomycin (final concentration, $0.1 \mathrm{mg} / \mathrm{ml}$ ) in a humidified atmosphere of $5 \% \mathrm{CO}_{2}$ and $95 \%$ air at $37^{\circ} \mathrm{C}$. Cytosine arabinoside $(5 \mu \mathrm{M})$ was added to culture medium 2 days after seeding.

\section{Assay of CaMKII activity in cultured hippocampal neurons}

CaMKII activity in cultured rat hippocampal neurons was assayed by the method as previously described $[5,10]$. Cultured neurons were treated with indomethacin in the presence and absence of KN93 or $\mathrm{H}-89$ at $37^{\circ} \mathrm{C}$ for $10 \mathrm{~min}$ in an extracellular solution [137 mM NaCl, $5.4 \mathrm{mM} \mathrm{KCl}, 10 \mathrm{mM} \mathrm{MgCl} \mathrm{z}^{\prime}, 0.3$ $\mathrm{mM} \mathrm{Na}_{2} \mathrm{HPO}_{4^{\prime}} 0.4 \mathrm{mM} \mathrm{K}_{2} \mathrm{HPO}_{4}$, and $20 \mathrm{mM}$ HEPES, $\mathrm{pH}$ 7.2]. Then, cells were rinsed with $100 \mu \mathrm{lof} \mathrm{Ca}^{2+}$-free phosphate-buffered saline and incubated at $30^{\circ} \mathrm{C}$ for $15 \mathrm{~min}$ in $50 \mu \mathrm{l}$ of the extracellular solution containing 
Fig. 1. Schematic CaMKII activation pathway. Autophos, auto-phosphorylation.

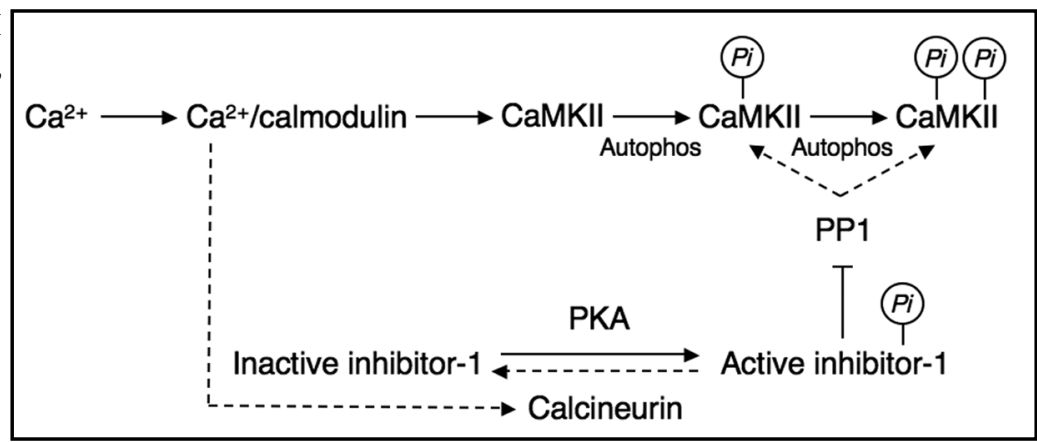

$50 \mu \mathrm{g} / \mathrm{ml}$ digitonin, $25 \mathrm{mM}$ glycerol 2-phosphate, $200 \mu \mathrm{M}$ ATP, and $100 \mu \mathrm{M}$ synthetic CaMKII substrate peptide (Lys-Lys-Ala-Leu-Arg-Arg-Gln-Glu-Thr-Val-Asp-Ala-Leu) (Calbiochem, San Diego, USA). The supernatants were collected and boiled at $100^{\circ} \mathrm{C}$ for $5 \mathrm{~min}$ to terminate the reaction. Aliquot of the solution $(20 \mu \mathrm{l})$ was loaded onto a reversed phase high-performance liquid chromatography (HPLC)(LC-10ATvp, Shimadzu, Kyoto, Japan). A substrate peptide peak and a new product peak were detected at an absorbance of $214 \mathrm{~nm}$ (SPD-10Avp UV-Vis detector, Shimadzu), and the peaks were confirmed unphosphorylated and phosphorylated substrate peptide, respectively, in the analysis of matrix-assisted laser desorption ionization time of flight mass spectrometry (Voyager DE-STR, PE Biosystems Inc., Foster City, USA). Areas for unphosphorylated and phosphorylated substrate peptide were measured (total area corresponds to concentration of substrate peptide for CaMKII used here). The amount of phosphorylated substrate peptide ( $\mathrm{pmol} / \mathrm{min} / \mu \mathrm{g}$ cell protein) was calculated and used as an index of CaMKII activity.

\section{Assay of CaMKII activity under the cell-free conditions}

CaMKII activity under the cell-free conditions was assayed by the method as previously described [10]. A synthetic CaMKII substrate peptide $(10 \mu \mathrm{M})$ (Calbiochem) was reacted with CaMKII (5 U)(Calbiochem) in a reaction medium ( $25 \mu \mathrm{l}, \mathrm{pH}$ 8.0) containing $40 \mathrm{mM}$ HEPES, $5 \mathrm{mM}$ Mg-acetate, $0.4 \mathrm{mM} \mathrm{CaCl}{ }_{2}, 0.1 \mathrm{mM}$ ATP, $0.1 \mathrm{mM}$ EGTA, $1 \mu \mathrm{M}$ calmodulin (Calbiochem) in the presence and absence of indomethacin at $35^{\circ} \mathrm{C}$ for $10 \mathrm{~min}$, and the reaction was terminated at $100^{\circ} \mathrm{C}$ for $5 \mathrm{~min}$. Aliquot of each solution $(15 \mu \mathrm{l})$ was injected onto the column ( $250 \mathrm{~mm} \times 4.6 \mathrm{~mm}$ )(COSMOSIL 5C18-AR-II, Nacalai Tesque, Kyoto, Japan), and loaded onto the reversed phase HPLC system (LC-10ATvp, Shimadzu). Unphosphorylated and phosphorylated peptides were detected at an absorbance of $214 \mathrm{~nm}$ (SPD-10Avp UV-Vis detector, Shimadzu). The amount of phosphorylated substrate peptide ( $\mathrm{pmol} / \mathrm{min}$ ) was calculated and used as an index of CaMKII activity.

Assay of protein kinase A (PKA) activity under the cell-free conditions

PKA activity under the cell-free conditions was assayed by the method as previously described [8]. A synthetic PKA substrate peptide (Leu-Arg-Arg-Ala-Ser-Leu-Gly) $(10 \mu \mathrm{M})$ (Calbiochem) was reacted with PKA (Calbiochem) in a reaction medium (25 $\mu$ l) containing $50 \mathrm{mM}$ Tris- $\mathrm{HCl}(\mathrm{pH} 7.5), 10 \mathrm{mM} \mathrm{MgCl}, 0.2$ $\mathrm{mM}$ ATP in the presence and absence of indomethacin at $30^{\circ} \mathrm{C}$ for $10 \mathrm{~min}$. The reaction was terminated at $100^{\circ} \mathrm{C}$ for $5 \mathrm{~min}$. Aliquot of the solution $(10 \mu \mathrm{l})$ was injected onto the column $(250 \mathrm{~mm} \times 4.6 \mathrm{~mm})$ (COSMOSIL 5C18-AR-II, Nacalai Tesque), and loaded onto the reversed phase HPLC system (LC-10ATvp, Shimadzu). Unphosphorylated and phosphorylated peptides were detected at an absorbance of $214 \mathrm{~nm}$ (SPD-10Avp UV-Vis detector, Shimadzu). The amount of phosphorylated substrate peptide ( $\mathrm{pmol} / \mathrm{min}$ ) was calculated and used as an index of PKA activity.

\section{Assay of PP1, PP2A, and PTP1B activities under the cell-free conditions}

Activities of protein phosphatases under the cell-free conditions were assayed by the partially modified method as previously described $[11,12]$. The human recombinant PP1 was purchased from New England BioLabs Inc. (Ipswich, MA, USA) and the human recombinant PP2A from Millipore (Billerica, MA, USA). The human PTP1B was cloned into pGEX-6P-3 vector with a GST tag at the $\mathrm{NH}_{2}$ terminus, and expressed in competent E. coli BL21 (DE3), suitable for transformation and protein expression. GST-fusion PTP1B was affinity-purified using Glutathione Sepharose 4B (GE Healthcare Bio-Science KK, Tokyo, Japan). Each phosphatase activity was assayed by reacting with $p$-nitrophenyl phosphate ( $p$-NPP)(Sigma, St. Louis, MO, USA) as a substrate. Enzyme was preincubated at $30^{\circ} \mathrm{C}$ (for PP1) or $37^{\circ} \mathrm{C}$ (for PP2A and PTP1B) for $30 \mathrm{~min}$ 
Fig. 2. Structure of fluorescein-conjugated indomethacin.

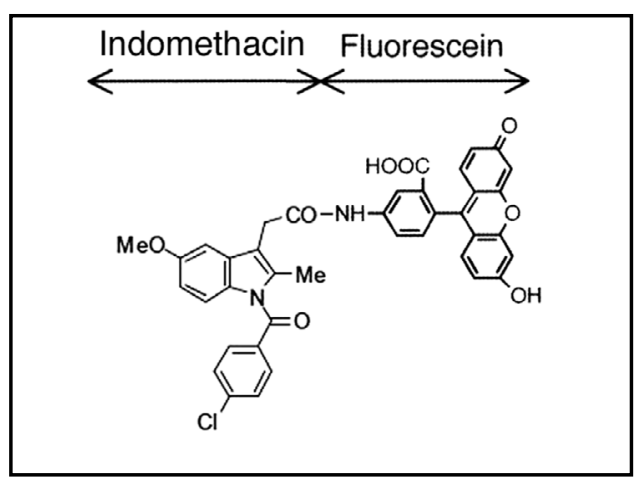

in a reaction medium [50 mM HEPES, $100 \mathrm{mM} \mathrm{NaCl}, 2 \mathrm{mM}$ dithiothreitol, 0.01\% (v/v) Brij-35, $1 \mathrm{mM} \mathrm{MnCl}_{2}$, pH 7.5 for PP1; 50 mM Tris-HCl, 0.1 mM EGTA, 0.1\% (v/v) 2-mercaptoethanol, pH 7.0 for PP2A; and 50 mM HEPES, $1 \mathrm{mM}$ EDTA, $50 \mathrm{mM} \mathrm{NaCl}, 1 \mathrm{mM}$ dithiothreitol, pH 7.2 for PTP1B] in the presence and absence of phosphatase inhibitors or indomethacin. Then, $p$-NPP at a concentration of $5 \mathrm{mM}$ for PP1, $500 \mu \mathrm{M}$ for PP2A, and $10 \mathrm{mM}$ for PTP1B was added to the reaction medium followed by 60 -min incubation, and the reaction was terminated by adding $0.1 \mathrm{~N} \mathrm{NaOH}$. Dephosphorylated $p$-NPP, i.e., $p$-NP, was quantified at an absorbance of $405 \mathrm{~nm}$ with a SpectraMax PLUS384 (Molecular Devices, Sunnyvale, CA, USA).

\section{Synthesis of fluorescein-conjugated indomethacin}

${ }^{1} \mathrm{H}-\mathrm{NMR}$ spectra were recorded on a JNM-ECX400 spectrometer (JEOL Ltd., Tokyo, Japan), operating at $400 \mathrm{MHz}$. Chemical shifts were reported downfield from $\mathrm{CHCl}_{3}(\delta=7.26)$ for ${ }^{1} \mathrm{H}-\mathrm{NMR}$. ESI-MS spectra were taken on a micrOTOF-Q mass spectrometer (Bruker Daltonics Inc., Billerica, MA, USA). Column chromatography was performed with a silica gel 60 (40-50 $\mu \mathrm{m}$ and 40-100 $\mu \mathrm{m})$ (Kanto Chemical Co., Tokyo, Japan). All reactions were monitored by thin-layer chromatography carried out on a $0.25 \mathrm{~mm}$ E. silica gel plates 60 F254 (Merck Ltd., Darmstadt, Germany), using UV light, iodine, m-bromo cresol green, 5\% (v/v) ethanolic phosphomolybdic acid solution, and heat as developing agents.

Fluorescein-conjugated indomethacin (Fig. 2) was synthesized by the following method. HBTU (58 mg, $0.15 \mathrm{mmol})$ and triethylamine $(0.021 \mathrm{~mL}, 0.15 \mathrm{mmol})$ were added to a solution containing indomethacin (50 $\mathrm{mg}, 0.14 \mathrm{mmol}$ ) and 5-aminofluorescein (53 $\mathrm{mg}, 0.15 \mathrm{mmol}$ ) in DMF (2 ml) under ice-cooling. The mixture was stirred for $8 \mathrm{~h}$ at room temperature and then, water was added. The aqueous layer was extracted with ethyl acetate, and the combined organic layers were dried over anhydrous $\mathrm{MgSO}_{4}$, and concentrated under reduced pressure. The crude product was purified by silica gel column chromatography (hexane:ethyl acetate $=2: 1)$ to give the desired compound $(15 \mathrm{mg}, 15 \%)$ as an orange solid. ${ }^{1} \mathrm{H}-\mathrm{NMR}(400 \mathrm{MHz}, \mathrm{CDCl} 3) \delta$ 2.45 (s, 3H), 3.82 (s, 3H), 3.91 (s, 2H), 4.09-4.20 (br s, 1H), 6.15-6.45 (br s, 1H), 6.49 (dd, J = 7.8 and $1.8 \mathrm{~Hz}$, $1 \mathrm{H}), 6.64(\mathrm{~s}, 1 \mathrm{H}), 6.65(\mathrm{~d}, J=7.8 \mathrm{~Hz}, 1 \mathrm{H}), 6.69(\mathrm{dd}, J=9.1$ and $2.3 \mathrm{~Hz}, 1 \mathrm{H}), 6.73(\mathrm{dd}, J=7.3 \mathrm{and} 1.8 \mathrm{~Hz}, 1 \mathrm{H})$, $6.83(\mathrm{~d}, J=7.3 \mathrm{~Hz}, 1 \mathrm{H}), 6.85(\mathrm{~d}, J=8.2 \mathrm{~Hz}, 1 \mathrm{H}), 6.87(\mathrm{~d}, J=9.2 \mathrm{~Hz}, 1 \mathrm{H}), 6.91(\mathrm{dd}, J=8.2 \mathrm{and} 1.8 \mathrm{~Hz}, 1 \mathrm{H}), 7.00(\mathrm{~d}$, $J=1.8 \mathrm{~Hz}, 1 \mathrm{H}), 7.03(\mathrm{~d}, J=2.3 \mathrm{~Hz}, 1 \mathrm{H}), 7.16(\mathrm{~d}, J=1.8 \mathrm{~Hz}, 1 \mathrm{H}), 7.47(\mathrm{~d}, J=8.3 \mathrm{~Hz}, 2 \mathrm{H}), 7.67(\mathrm{~d}, J=8.3 \mathrm{~Hz}, 2 \mathrm{H})$; ESI-HRMS (negative ion, sodium formate) calculated for $\mathrm{C}_{30} \mathrm{H}_{26} \mathrm{ClN}_{2} \mathrm{O}_{6}([\mathrm{M}-\mathrm{H}]]^{-}$) 685.1378; found 685.1372.

\section{Assay for indomethacin binding to PP1, PP2A, and PTP1B}

Each phosphatase was separated by blue native-polyacrylamide gel electrophoresis (PAGE). Briefly, proteins were dissolved in a sample buffer [50 mM immidazole, $50 \mathrm{mM} \mathrm{NaCl}, 5 \mathrm{mM}$ 6-aminohexanoic acid, $40 \%(\mathrm{v} / \mathrm{v}$ ) glycerol, $0.5 \%(\mathrm{w} / \mathrm{v})$ Coomassie G-250 and 1\% (w/v) digitonin, $\mathrm{pH} 7.0$ ], and electrophoresed onto a TGX Gel (BioRad, Hercules, CA, USA) in a cathode buffer [50 mM Tricine, $7.5 \mathrm{mM}$ imidazole, and $0.02 \%(\mathrm{w} / \mathrm{v}$ ) Coomassie G-250, pH 7.0] and an anode buffer (25 mM imidazole, pH 7.0). After pretreatment with or without $1 \mathrm{mM}$ non-conjugated indomethacin at $30^{\circ} \mathrm{C}$ (for PP1) or $37^{\circ} \mathrm{C}$ (for PP2A and PTP1B) for $30 \mathrm{~min}$, gels were reacted with $1 \mathrm{mM}$ fluorescein-conjugated indomethacin in the presence and absence of 1 $\mathrm{mM}$ non-conjugated indomethacin at $30^{\circ} \mathrm{C}$ (for PP1) or $37^{\circ} \mathrm{C}$ (for PP2A and PTP1B) for 60 min. Fluorescent signals were visualized using FluoroPhoreStar3000 (Anatech, Tokyo, Japan).

Statistical analysis

Statistical analysis was carried out using Dunnett's test. 


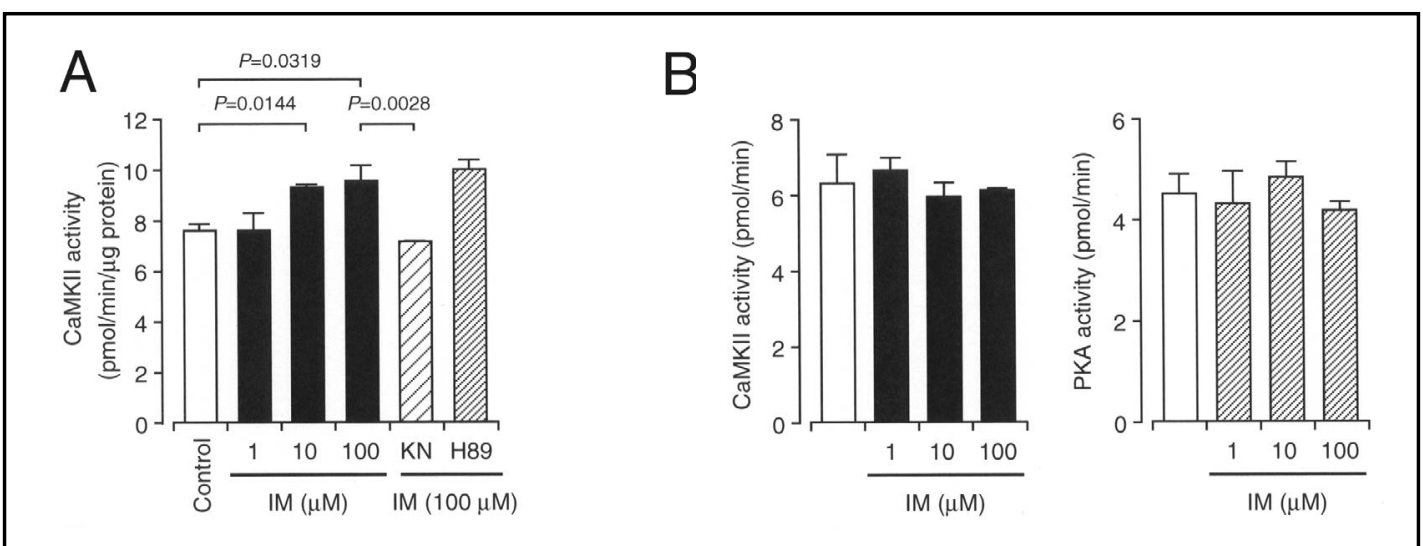

Fig. 3. Indomethacin-induced CaMKII activation. (A) Cultured rat hippocampal neurons were untreated and treated with indomethacin (IM) at concentrations as indicated in the presence and absence of KN-93 $(\mathrm{KN})(3 \mu \mathrm{M})$ or H-89 (H89)(1 $\mu \mathrm{M})$, and CaMKII activity was assayed. In the graph, each column represents the mean $( \pm \mathrm{SEM})$ CaMKII activity ( $\mathrm{pmol} / \mathrm{min} / \mu \mathrm{g}$ cell protein $)(\mathrm{n}=8$ independent experiments). $P$ values, Dunnett's test. (B) CaMKII activity (left panel) and PKA activity (right panel) were assayed under the cellfree conditions. In the graphs, each column represents the mean $( \pm \mathrm{SEM})$ CaMKII activity $(\mathrm{pmol} / \mathrm{min})(\mathrm{n}=6$ independent experiments) or PKA activity (pmol/min)(n=6 independent experiments). Note that $P$ values are not shown in the data without significant difference.

\section{Results}

Indomethacin activates CaMKII in cultured rat hippocampal neurons

We initially examined whether indomethacin activates CaMKII. Indomethacin activated CaMKII in cultured rat hippocampal neurons in a concentration (1-100 $\mu \mathrm{M})$-dependent manner, the extent reaching $126 \%$ of basal CaMKII activity at $100 \mu \mathrm{M}$ (Fig. 3A). The effect was

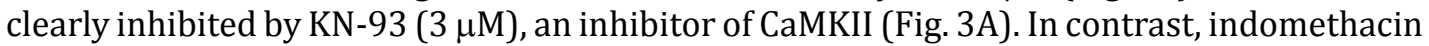
did not activate CaMKII under the cell-free conditions (Fig. 3B). These results indicate that indomethacin activates CaMKII, but not directly.

In the established CaMKII activation pathway, CaMKII is activated through $\mathrm{Ca}^{2+} /$ calmodulin binding and the ensuing autophosphorylation, but CaMKII is otherwise inactivated by PP1-mediated dephosphorylation of phosphorylated CaMKII [13-15] (Fig. 1). PP1 is suppressed by an active form of protein phosphatase inhibitor-1. PKA phosphorylates and activates protein phosphatase inhibitor-1, but otherwise calcineurin dephosphorylates and inactivates protein phosphatase inhibitor-1 [13-15] (Fig. 1). PKA, accordingly, could indirectly activate CaMKII by activating protein phosphatase inhibitor-1, thereby inhibiting PP1 [13-15] (Fig. 1). Indomethacin-induced CaMKII activation was not inhibited by H-89 (1 $\mu \mathrm{M}$ ), an inhibitor of PKA, in cultured rat hippocampal neurons (Fig. 3A), and no activation of PKA was obtained with indomethacin under the cell-free conditions (Fig. 3B). These results rule out the implication of PKA in indomethacin-induced CaMKII activation.

\section{Indomethacin activates CaMKII by binding to and directly inhibiting PP1}

We postulated that indomethacin might directly inhibit PP1. To examine the effect of indomethacin on protein phosphatases, we assayed activities of protein phosphatases using three different inhibitors such as calyculin A, okadaic acid, and sodium orthovanadate $\left(\mathrm{Na}_{3} \mathrm{VO}_{4}\right)$. Calyculin A inhibits both PP1 and PP2A, but otherwise okadaic acid specifically reduces PP2A activity [16]. Sodium orthovanadate is widely used to inhibit PTP1B [17]. In the cell-free PP1 assay, calyculin A inhibited PP1 activity in a concentration (1-100 nM)dependent manner (Fig. 4A). Indomethacin also attenuated PP1 activity in a concentration $(10 \mu \mathrm{M}-1 \mathrm{mM})$-dependent manner, the extent reaching approximately $70 \%$ of basal activity 


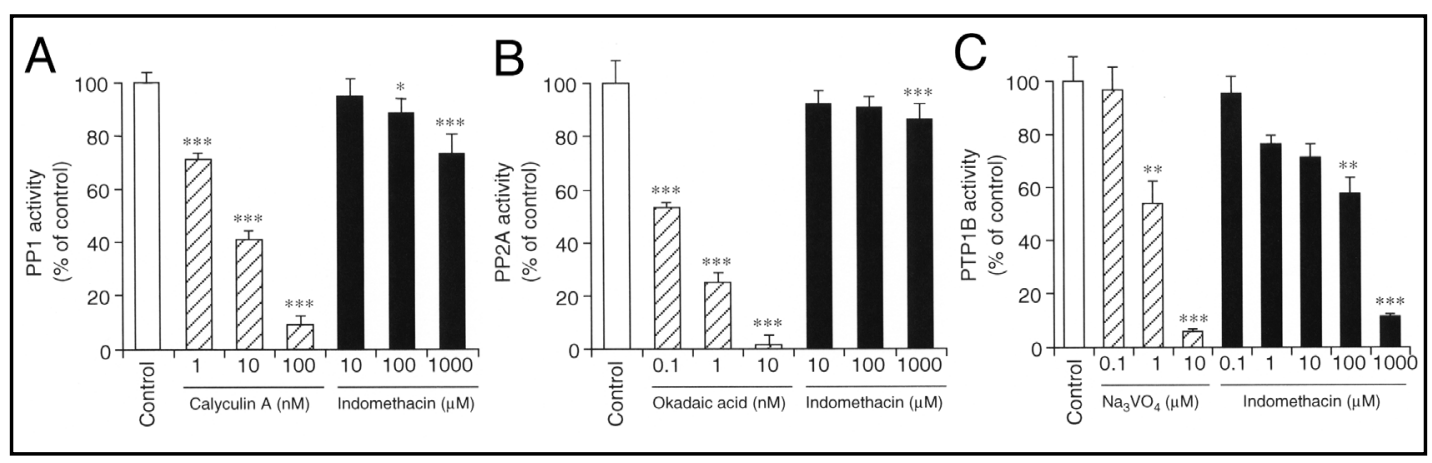

Fig. 4. Indomethacin-induced protein phosphatase inhibition. PP1 (A), PP2A (B), or PTP1B (C) was reacted with $p$-NPP and dephosphorylated $p$-NPP was quantified. In the graphs, each column represents the mean $\left( \pm\right.$ SEM) percentage of basal phosphatase activity (control) $\left(\mathrm{n}=4\right.$ independent experiments). ${ }^{*} P<0.01$, ${ }^{* *} P<0.001,{ }^{* * *} P<0.0001$, Dunnett's test.

Fig. 5. Indomethacin binding to protein phosphatases. Electrophoresed PP1 (A), PP2A (B), or PTP1B (C) was incubated with fluorescein-conjugated indomethacin (Fluo$\mathrm{IM})(1 \mathrm{mM})$ in the absence and presence of non-conjugated indomethacin (Co-IM) (1 $\mathrm{mM}$ ) or before and after pretreatment with non-conjugated indomethacin (Pre-IM) (1 mM), and fluorescent signals were detected ( $n=4$ independent experiments). CBB, Coomassie brilliant blue staining. Note that no fluorescent signal band was found at the GST molecule.

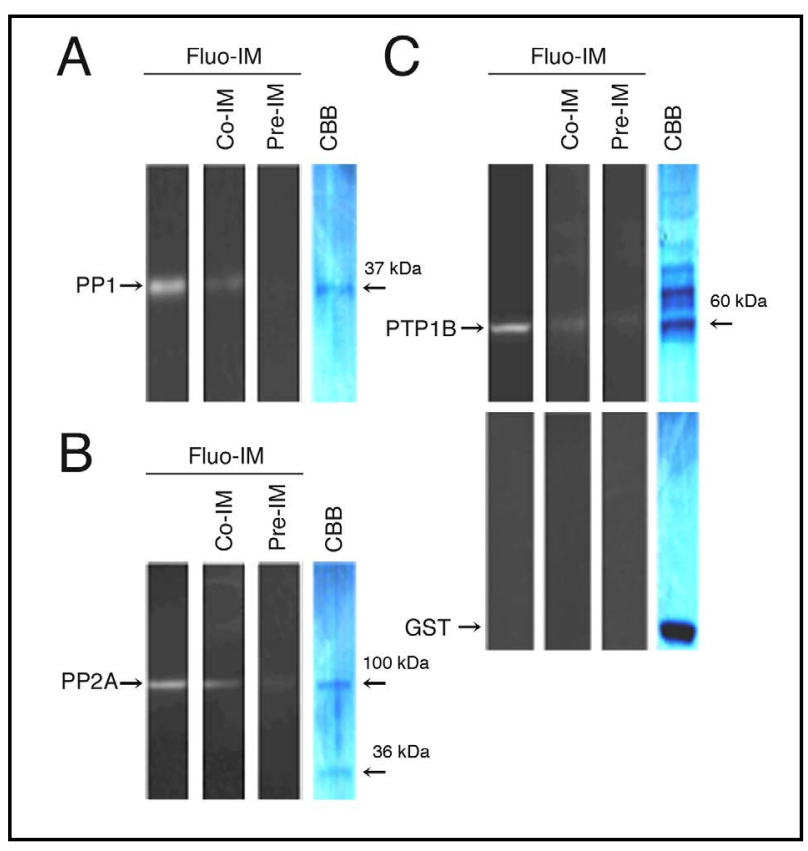

at $1 \mathrm{mM}$ (Fig. 4A). This suggests that indomethacin directly inhibits PP1 activity, thereby activating CaMKII.

To obtain further evidence for this note, we examined whether indomethacin binds to PP1 using a fluorescein-conjugated indomethacin. In the indomethacin binding assay, a fluorescent signal band was detected at $37 \mathrm{kDa}$, corresponding to PP1 separated on blue nativePAGE, and the signal band was blurred by co-treatment with non-conjugated indomethacin as a competitor or abolished by pretreatment with non-conjugated indomethacin (Fig. 5A). Overall, it leads to a conclusion that indomethacin activates CaMKII by directly binding to and inhibiting PP1.

\section{Indomethacin inhibits PP2A and PTP1B through its direct binding}

Our final attempt was to see the effect of indomethacin on other protein phosphatases such as PP2A and PTP1B. In the cell-free PP2A assay, okadaic acid significantly inhibited PP2A activity in a concentration (0.1-10 nM)-dependent manner (Fig. 4B). A higher concentration (1 $\mathrm{mM}$ ) of indomethacin reduced PP2A activity to nearly $90 \%$ of basal activity, although lower concentrations less than $100 \mu \mathrm{M}$ had no effect (Fig. 4B). In the blue native-PAGE, 
two proteins were separated at 36 and $100 \mathrm{kDa}$ (Fig. 5B). A protein at $36 \mathrm{kDa}$ was in well agreement with the molecular weight for the catalytic subunit of PP2A. In the indomethacin binding assay, a single fluorescent signal band was detected at $100 \mathrm{kDa}$, corresponding to a complete PP2A consisting of the structural, regulatory, and catalytic subunits, and the signal band is attenuated by co-treatment with non-conjugated indomethacin or blocked by pretreatment with non-conjugated indomethacin (Fig. 5B).

In the cell-free PTP1B assay, sodium orthovanadate inhibited PTP1B activity in a concentration (0.1-10 $\mu \mathrm{M}$ )-dependentmanner (Fig. 4C). Likewise, indomethacinalso inhibited PTP1B activity in a concentration $(0.1 \mu \mathrm{M}-1 \mathrm{mM})$-dependent manner, the extent reaching $10 \%$ of basal activity (Fig. 4C). In the blue native-PAGE, several molecular weights of proteins were found (Fig. 5C), suggesting contamination of other proteins in addition to PTP1B. In the indomethacin binding assay, however, fluorescein-conjugated indomethacin produced a single fluorescent signal band at $60 \mathrm{kDa}$, corresponding to PTP1B, that is suppressed or abolished by co-treatment or pretreatment with non-conjugated indomethacin (Fig. 5C). Taken together, indomethacin appears to directly bind to and inhibit protein phosphatases such as PP1, PP2A, and PTP1B, with the potency varying among protein phosphatases.

\section{Discussion}

In the present study, indomethacin activated CaMKII in hippocampal neurons, but no CaMKII activation was found under the cell-free conditions, suggesting that indomethacin indirectly activates CaMKII. For CaMKII activation pathway, CaMKII binds to $\mathrm{Ca}^{2+} /$ calmodulin and is activated through its autophosphorylation. PP1 dephosphorylates phosphorylated CaMKII to inactivate it. PP1 activity is inhibited by an active form of protein phosphatase inhibitor-1. Protein phosphatase inhibitor-1 is activated by PKA-mediated phosphorylation, but otherwise it is inactivated by calcineurin-mediated dephosphorylation [13-15] (Fig. 1). Plausible pathways underlying indomethacin-induced CaMKII activation include that 1) indomethacin activates PKA, to phosphorylate and activate protein phosphatase inhibitor1, leading to inhibition of PP1 activity, 2) indomethacin directly binds to and inhibits PP1 activity, and 3) indomethacin inhibits calcineurin, causing indirect activation of protein phosphatase inhibitor-1. In the present study, indomethacin-induced CaMKII activation was not affected by the PKA inhibitor H-89 and indomethacin did not activate PKA under the cell-free conditions. This excludes the participation of PKA in indomethacin-induced CaMKII activation.

In the cell-free PP1 assay, indomethacin reduced PP1 activity in a concentration (10 $\mu \mathrm{M}-1 \mathrm{mM}$ )-dependent manner. In the indomethacin binding assay, indomethacin actually bound to PP1. Collectively, these results suggest that indomethacin inhibits PP1 through its direct binding, thereby activating CaMKII. A pathway for CaMKII activation in association with suppressed calcineurin, however, is not presently ruled out.

Evidence has pointed to physiological significance for a CaMKII/PP1 switch in synaptic memory [18]. In our earlier study, indomethacin facilitated hippocampal synaptic transmission by stimulating presynaptic glutamate release through a CaMKII pathway, in a fashion that mimics long-term potentiation, a cellular model for learning and memory [5]. The indomethacin action could account for improvement of learning and memory impairment or enhancement in learning and memory potentials [5]. The results of the present study may represent a CaMKII/PP1 switch relevant to cognitive functions under the regulation of indomethacin, i.e., a switch from CaMKII inhibition by PP1 to CaMKII activation by PP1 inhibition.

Of particular interest is that like PP1 indomethacin inhibits PP2A and PTP1B, possibly through its direct binding. To our knowledge, this is the first to show the inhibitory action of indomethacin on protein phosphatases. PP2A is a major serine/threonine protein phosphatase in mammalian cells. PP2A dephosphorylates phosphorylated Akt at Thr308 $[19,20]$ and may serve as a tumor suppressor [21]. Conversely, reduced PP2A activity could 
activate MEK, independently of Raf [22]. PTP1B, on the other hand, functions as a negative regulator of insulin receptor signaling pathways by dephosphorylating the receptor [23-25]. In addition, PTP1B may suppress proliferation or differentiation of tumor cells by inhibiting receptor tyrosine kinases such as epidermal growth factor and platelet-derived growth factor receptors [26]. Physiological significance for indomethacin-induced inhibition of PP2A or PTP1B, however, remains to be explored. To address this point, we are currently carrying out further experiments.

In conclusion, the results of the present study show that indomethacin indirectly activates CaMKII, possibly by directly binding to and inhibiting PP1. The results also show that indomethacin inhibits PP2A and PTP1B, possibly through its direct binding. These extend our knowledge regarding the indomethacin actions, distinct from COX inhibition.

\section{References}

1 Etminan M, Gill S, Samii A: Effect of nonsteroidal anti-inflammatory drugs on risk of Alzheimer's disease: systematic review and meta-analysis of observational studies. Br Med J 2003;327:128.

-2 in t' Veld BA, Ruitenberg A, Hofman A, Launer LJ, van Duijn CM, Stijnen T, Breteler MM, Stricker B: Nonsteroidal antiinflammatory drugs and the risk of Alzheimer's disease. N Eng J Med 2001;345:15151521.

3 Szekely CA, Thorne JE, Zandi PP, Ek M, Messias E, Breitner JC, Goodman SN: Nonsteroidal anti-inflammatory drugs for the prevention of Alzheimer's disease: a systematic review. Neuroepidemiology 2004;23:159169.

4 Townsend KP, Praticò D: Novel therapeutic opportunities for Alzheimer's disease: focus on nonsteroidal anti-inflammatory drugs. FASEB J 2005;19:1592-1601.

-5 Kanno T, Yaguchi T, Nagata T, Shimizu T, Tanaka A, Nishizaki T: Indomethacin enhances learning and memory potential by interacting with CaMKII. J Cell Physiol 2011;227:919-926.

-6 Kanno T, Yaguchi T, Nagata T, Nishizaki T: Indomethacin activates protein kinase C and potentiates $\alpha 7$ ACh receptor responses. Cell Physiol Biochem 2012;29:189-196.

7 Kanno T, Tsuchiya A, Shimizu T, Tanaka A, Nishizaki T: Novel indomethacin action: selective and direct activation of protein kinase C-ع. J Cell Physiol 2012;30:771-777.

$>8$ Kanno T, Yamamoto H, Yaguchi T, Hi R, Mukasa T, Fujikawa H, Nagata T, Yamamoto S, Tanaka A, Nishizaki T: The linoleic acid derivative DCP-LA selectively activates PKC- $\varepsilon$, possibly binding to the phosphatidylserine binding site. J Lipid Res 2006;47:1146-1156.

-9 Shimizu T, Kanno T, Tanaka A, Nishizaki T: $\alpha, \beta$-DCP-LA selectively activates PKC- $\varepsilon$ and stimulates neurotransmitter release with the highest potency among 4 diastereomers. Cell Physiol Biochem 2011;27:149-158.

10 Kanno T, Yaguchi T, Nagata T, Tanaka A, Nishizaki T: DCP-LA stimulates AMPA receptor exocytosis through CaMKII activation due to PP-1 inhibition. J Cell Physiol 2009;221:183-188.

11 Baba Y, Hirukawa N, Tanohira N, Sodeoka M: Structure-based design of a highly selective catalytic sitedirected inhibitor of Ser/Thr protein phosphatase 2B (calcineurin). J Am Chem Soc 2003;125;9740-9749.

12 Rice RL, Rusnak JM, Yokokawa F, Yokokawa S, Messner DJ, Boynton AL, Wipf P, Lazo JS: A targeted library of small-molecule, tyrosine, and dual-specificity phosphatase inhibitors derived from a rational core design and random side chain variation. Biochemistry 1997;36:15965-15974.

13 Endo S, Zhou X, Connor J, Wang B, Shenolikar S: Multiple structural elements define the specificity of recombinant human inhibitor-1 as a protein phosphatase-1 inhibitor. Biochemistry 1996;35:5220-5228.

14 Huang KX, Paudel HK: Ser ${ }^{67}$-phosphorylated inhibitor 1 is a potent protein phosphatase 1 inhibitor. Proc Natl Acad Sci USA 2000;97:5824-5829.

15 Kubokawa M, Nakamura K, Komagiri Y: Interaction between calcineurin and $\mathrm{Ca}^{2+} /$ calmodulin kinase-II in modulating cellular functions. Enzyme Res 2011;2011:587359.

16 Swingle M, Ni L, Honkanen RE: Small-molecule inhibitors of ser/thr protein phosphatases: specificity, use and common forms of abuse. Methods Mol Biol 2007;365:23-38. 
17 Swarup G, Cohen S, Garbers DL: Inhibition of membrane phosphotyrosyl-protein phosphatase activity by vanadate. Biochem Biophys Res Commun 1982;107:1104-1109.

18 Lisman JE, Zhabotinsky AM: A model of synaptic memory: a CaMKII/PP1 switch that potentiates transmission by organizing an AMPA receptor anchoring assembly. Neuron 2001;31:191-201.

19 Millward TA, Zolnierowicz S, Hemmings BA: Regulation of protein kinase cascades by protein phosphatase 2A. Trends Biochem Sci 1999;24:186-191.

20 Gao T, Furnari F, Newton AC: PHLPP: a phosphatase that directly dephosphorylates Akt, promotes apoptosis, and suppresses tumor growth. Mol Cell 2005;18:13-24.

21 Zhang Q, Claret FX: Phosphatases: the new brakes for cancer development? Enzyme Res 2012;2012:659649.

22 Bae D, Ceryak S: Raf-independent, PP2A-dependent MEK activation in response to ERK silencing. Biochem Biophys Res Commun 2009;385:523-527.

23 Byon JC, Kusari AB, Kusari J: Protein-tyrosine phosphatase-1B acts as a negative regulator of insulin signal transduction. Mol Cell Biochem 1998;182:101-108.

24 Walchli S, Curchod ML, Gobert RP, Arkinstall S, Hooft van Huijsduijnen R: Identification of tyrosine phosphatases that dephosphorylate the insulin receptor. A brute force approach based on 'substratetrapping' mutants. J Biol Chem 2000;275:9792-9796.

25 Salmeen A, Andersen JN, Myers MP, Tonks NK, Barford D: Molecular basis for the dephosphorylation of the activation segment of the insulin receptor by protein tyrosine phosphatase 1B. Mol Cell 2000;6:14011412.

26 Haj FG, Markova B, Klaman LD, Bohmer FD, Neel BG: Regulation of receptor tyrosine kinase signaling by protein tyrosine phosphatase-1B. J Biol Chem 2003;278:739-744. 